\title{
4 New Communication Technologies
}

In the recent past, new media has played an important role in both controlling and expanding democratic space. This phenomenon seems to have had a significant impact on recent elections in transition democracies such as Kenya. Most new media forms are emerging from the Internet and mobile (cellular) telephones.

For societies emerging from years of single-party rule, a common dilemma for the fledgling political opposition has been how to mobilise supporters given the ruling party's domination of the normal channels of communication. Hence, new political campaigning strategies have emerged in response, including online chain-mail, ${ }^{29}$ campaigns through mobile phone text messaging and the use of cell phones to mobilise supporters into action. These methods open up a communication space that is beyond the reach of the traditional mass media. Given these developments, it is abundantly clear that traditional campaign regulations need to be updated to cover emerging forms of telecommunications.

\section{New Interactive Media}

Modern political campaigns in transition democracies tend to embrace what is happening in developed democracies. With the advent of cable communication, mobile telephony, satellite television and the proliferation of private broadcasting, political campaigns have intensified to such an extent that a new political communication culture is evolving. Yet existing practices and principles of media behaviour in elections were largely developed for what is now regarded to be 'old' media: newspapers, radio and television. Some of these have been overtaken by the emergent new forms of media.

New communication technologies offer numerous positive opportunities for the electoral process itself. These include voter registration (and even voting) via the Internet or cell phone. This is in addition to the role that these technologies could play as news or campaigning media. In any event, many assumptions that underpin the regulation of conventional media do not apply to new media. For example, the World Wide Web ('the 
Web') has infinite space to publish material, yet the assumption behind broadcasting regulation is that the frequency spectrum is a finite resource that must be shared.

New technologies also help to challenge the dominance of powerful corporate or governmental voices in the media. It is far easier for individuals or small groups to set up websites or send text messages on cell phones than it is to launch newspapers or television stations. Internet and other new communication technologies are carried on media (such as telephone lines) owned by governments or large corporations, but this obstacle can be circumvented through direct broadcasts or satellite reception.

The main regulatory challenge posed by new media is that, unlike old media, it can only be regulated in ways that constitute censorship or restrict freedom of expression. Some common regulatory actions include interception of emails, closure of websites, disabling of text message services, and pressure or legal action against Internet service providers. This compares to the judicial measures usually used to regulate 'old media'.

The diverse reach of new media deserves further mention, especially its radical challenge to traditional views of media conduct during elections. Election reporting blackouts, for example, have been rendered virtually obsolete by the activities of unregulated websites. At the same time, the global nature of the Internet renders its content beyond regulation by national electoral authorities. Attempts by regulators to close down websites are met by the creation of mirror sites (replicas) beyond the country's borders. Analysts caution that this regulatory challenge could rapidly extend beyond the written word, to Internet radio and television. Already new variants such as podcasting (the broadcasting of audio materials over the Internet), Really Simple Syndication (RSS) ${ }^{30}$ and peer-to-peer networks have taken root.

Because Internet services are still beyond the reach of a majority of people in developing countries, one might be tempted to ask: why does it matter? Yet where the 'elite' work as the information agency of a village, one Internet connection or one mobile telephone receiving a text (also known as a SMS or short message service) can inform the entire community.

\section{Communications Revolution}

Researchers and journalists agree that cell phones are the platform of now and the future. In his paper 'Mobile Phones, Identity and 
Discursive Intimacy', technology scholar Raul Pertierra (2005) asserts that recent trends suggest that cell phones are increasingly taking a major role in this communications revolution.

The interconnectivity of mobile telephony, computers, radio, television and print media are producing new communication structures, with often-unpredictable consequences. New media will bring about important social changes, from personal identity to political mobilisation, and from virtual spaces or simulated models to lived realities and embodied geographies. It is hoped that the new media may also assist in the gathering and dissemination of alternative information sources, creating virtual public spaces where citizens can debate vital issues and organise appropriate political action.

Pertierra, citing elections in the Philippines, says the cell phone was important in co-ordinating the movement of candidates and their supporters, as well as in the government's keeping a close watch on the activities of the political opposition. Pertierra argued that events such as weddings, baptisms, burials and senior citizens' meetings always draw large crowds and candidates made sure that they were present, and importantly that the cell phone played an important role in keeping track of these activities. ${ }^{31}$ In the 2007 Sierra Leone presidential elections, journalists despatched their stories from rural districts to editors in the capital Freetown via SMS and observer groups, including one from the Commonwealth Secretariat, convened news conferences by sending text messages to media hotlines or political reporters. ${ }^{32}$

\section{The Internet and Elections}

The Internet has been hailed as the next revolution in electoral communications, just as it is claimed to have revolutionised the global flow of information. Opinion polls are already conducted via the Internet, although these are still seriously unreliable. In a context where the conventional media is highly censored, the Internet can be an important means for small numbers of people to receive politically sensitive information, which can then be more widely circulated. In other words, for most of the globe, the significance of the Internet is more that it will enable alternative ideas to be put into circulation, rather than it serving as a means of mass communication by parties, candidates or electoral authorities. 
The 'convergence' between broadcasting and telecommunications - telephony has moved towards the use of satellites, while broadcasting has moved towards the use of fibre-optic cable - is also likely to lead to a closer linkage between traditional media and the Internet.

The Internet has become a major campaign tool for political groups. The United States provides the best example of hightech, Internet-based fundraising where, for example, US President Barack Obama raised millions of dollars via the medium for his successful campaign.

At the same time, Internet campaigning is gaining currency among the educated elite and young people in developing countries, including in Africa. However, the medium is still limited by poverty and to some extent the reluctance of politicians especially those who have been on the stage right from the independence era, who are cultured in the principle of 'strong-man leadership' rather than the possibility of spontaneous interaction with the electorate. Politicians' websites tend to carry the same material as that that is available in other traditional formats.

One other area of election-related Internet development is activism by NGOs. In the United States, election activism includes searchable online databases on financial contributions to the different candidates' campaigns or on a candidate's voting record. If applied honestly and accurately, these developments can only enhance democracy. A more problematic development, however, is the use of Internet reporting to subvert conventions that have been widely accepted by 'traditional' media, for example, reporting exit polls before voting has ended.

An important characteristic of the Internet is the ease of access for individuals and small organisations. For instance, the medium has lowered costs associated with traditional publishing (although the problem of quality control still exists). Lowered costs have also led to the emergence of 'blogging' (a contraction of the term 'web log'). These independent and often intemperate individual diaries ('blogs') have been condemned and praised in equal measure. Regardless, they are a political phenomenon that is here to stay.

Other technological developments within the Internet will also have political ramifications. The Really Simple Syndication (RSS news feeds) discussed above provide a means of disseminating news stories rapidly and at virtually no cost. Web 
video sites such as YouTube and peer-to-peer networks allow the simple, low-cost transfer of large files (such as audio and video files) to a wide audience. 'Podcasting' is a term coined to describe the broadcasting of audio materials over the Internet (and in theory their downloading to personal media players or for re-broadcast by local or community radio stations).

The Internet can also be an important way of distributing broadcast signals through streaming. This is a particularly effective way of making programming available to local or regional radio stations in large countries. Indonesia recently experimented with this approach, and reported a high potential for distributing voter education material or direct-access slots.

\section{Mobile Phones and Elections}

As earlier mentioned, wireless communication and cell phones are becoming increasingly widespread. In addition to voice calling, cell phones are a platform for new services such as text messaging, email and basic Internet browsing, all of which are potentially useful to the election process.

For instance, until recently home computers in Japan were considered the province of otaku (reclusive, obsessive intellectuals). Cell phones, on the other hand, have long been extremely popular and the primary interface of most Japanese users to email and the Internet. Cell phones also have special relevance for countries with a poor, fixed telephone infrastructure. Radio is by far the most dominant medium in Africa, and the recent proliferation of independent radio stations and cellular infrastructure is already affecting politics. In the run up to Ghana's December 2000 elections, radio phone-in shows pilloried the hand-picked successor of Jerry Rawlings, the outgoing president. The candidate, John Atta Mills, lost the election. During the election itself, voters used cell phones and talk radio to report voting fraud.

Two factors support common arguments that mobile phones are an important medium for electoral communication. First, ownership and access to cellular phones far outstrips that of fixed landlines. This disparity is especially apparent in poorer countries, but it is now a general phenomenon. Second, cell phones have potential as a 'broadcasting' medium that is incomparable to traditional landlines. While landlines could be used for voice and fax communications, cell phones can send and 
'... [D] uring the 2002 elections, reporters covering them would monitor proceedings,

including vote counting results in different locations, by calling or sending short text messages to each other. This meant they were able to pass the same information on to their respective media houses ...'

Joyce Mulama Inter-Press Service (IPS) news agency receive text messages, data audio and even video files.

The use of cell phones in political campaigning or broadcasting may not be fully developed, but the potential is obvious and is growing rapidly. The Philippines offers two well-documented examples. In 2001, a popular campaign against President Joseph Estrada was orchestrated by SMS, forcing him to resign. Then, in the 2004 presidential elections, texting proved to be a popular campaigning tool for the main candidates. ${ }^{33}$

It is hard to see how SMS could easily be brought within the regulatory ambit without resorting to heavy-handed censorship. Another concern is that text messaging, like email, can easily be 'spoofed'. This means that messages can be sent from masked or fake addresses (as with email 'spam' or junk mail), making the regulator's task even more difficult. Yet characteristics that make regulation difficult can also be positive: in the Zimbabwe elections in 2008, SMS was about the only major tool available to the opposition parties, as the country's mass media - owned by the government - offered limited or no coverage of opposition messages.

What has so far been confined to SMS could rapidly develop through audio and video files, with the development of 'third generation' (3G) phones capable of exchanging such files easily. This is where Internet-based techniques like podcasting and cellular telephony overlap. Political broadcasts could be distributed by a mixture of media, to be watched or listened to on telephones or personal stereo players. These technologies are potentially available to all players in election campaigns. Parties can use them to distribute campaign material, the media can use them to increase audience numbers and electoral managers can use them to educate voters and increase political participation. Indeed, President Barack Obama did exactly this during his 2008 election campaign.

Civil society groups and political parties have also experimented with text messaging to prevent elections fraud in the wake of the botched Kenya (2007) and Zimbabwe (2008) elections. In Ghana's December 2008 elections, NGOs under the umbrella group the Coalition of Domestic Election Observers (CODEO) used mobile phones to hinder the potential falsifying of results. According to the Financial Times:

The system works like this: volunteers with mobile phones monitor a representative sample of 1,000 out of some 21,000 polling 
stations. As voting gets under way, they send text messages containing data on the conduct in their polling station to a toll-free number. A cheat-sheet lists the codes. For example, a text containing 'Dl' means 'ballot box missing'. Mobile-based schemes have been used to monitor votes in Indonesia, Montenegro, Egypt and Sierra Leone in recent years, but the developers say Ghana has the most sophisticated version yet deployed. CODEO volunteers hope the SMS-based scheme can be replicated elsewhere to prevent incumbents leaning on electoral officials to bump up their tallies. ${ }^{34}$ 


\section{TESTIMONY}

\section{Joyce Mulama - Kenya}

Kenya held its last elections in December 2007 and the violence that followed them is well documented. Severe deficiencies within the electoral process and the sheer incompetence of the Electoral Commission of Kenya (ECK) have also been documented in a detailed manner by a Judicial Review Commission, which was created as part of a power-sharing agreement between the main political parties that contested that election - the Party of National Unity fronted by President

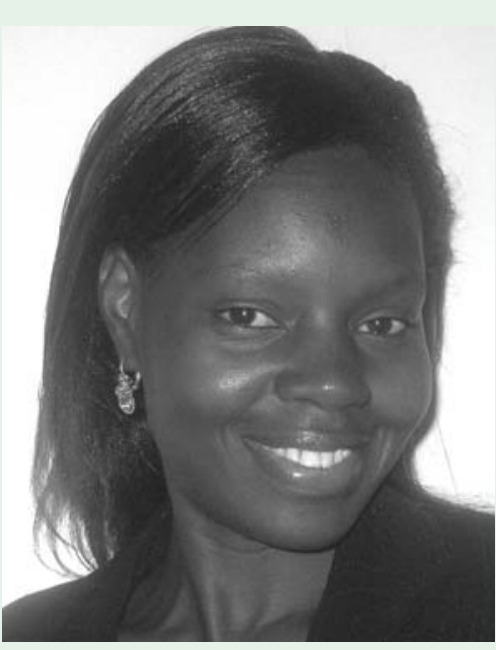
Mwai Kibaki and the Orange Democratic Movement of Raila Odinga, who took the post of Prime Minister in a political arrangement designed to end further bloodshed.

I will discuss a number of issues relevant to the electoral process in Kenya, focusing specifically on the pre-disputed results and period of violence period in the country. Because of the sensitivity of the subject, the importance of upholding high standards of objectivity in election reporting cannot be overemphasised. Politicians and political parties, however weak, expect not to be sidelined in terms of coverage. Yet, in the Kenyan situation, a number of media houses have been known to take visible sides. While it can be stated that over the years the mainstream media has become stronger and has demonstrated objective coverage of elections, the tabloid press - or the pink and yellow pages as they are better known in Kenya - has bent the rules of objective reporting and taken sides many times, rarely veiling their opinions. The reason sometimes lies in the fact that politicians own some of the tabloids and use them as propaganda tools. On a more positive note, however, the larger population pays more attention to the mainstream media, reading the 'gutter press' mostly for the entertainment that scandals and occasional heresy provide.

Timely information is of the essence in election coverage, from a moral viewpoint so that it may calm peoples' often-extreme anxiety, and on the commercial side to get to the market before the competition. All the mainstream electronic media have recently acquired equipment to enable them to present live coverage of events. This is already being applied in campaigns coverage, and boosted viewers during the elections in December 2007. Such swift information flow, together with an objective electoral commission, is known to have played a role before in frustrating attempts to falsify results of elections. In this respect, I have in mind the 2002 elections, when the Electoral Commission of Kenya chairman, Samuel Kivuitu, told the media, including myself, that the government was attempting to rig the election. His forthrightness and ensuing 
prompt media coverage, in addition to the greater vigilance by the opposition his statement generated, probably saved the day. Unfortunately, following the 2007 elections, he was quoted as saying he did not know whether President Mwai Kibaki had won, casting a huge shadow on the process. Mr Kivuitu later clarified that his statement had been taken out of context, and he actually meant he did not know whether the President had won 'fairly'. But the damage had already been done.

With live coverage comes the possibility of libel suits, because journalists seldom have much time to edit what will be broadcast. Hence, there is the need for extreme caution in this manner of reporting, despite the prompt coverage it allows of important events. Nonetheless, the greatest challenge of providing information quickly comes with the inaccessibility of remote areas, where even telephone network coverage is absent (unless media houses invest in costly satellite telephony). Network coverage notwithstanding, mobile phones have proved effective in ensuring the swift flow of information. During the 2002 elections, journalists covering them would monitor proceedings, including vote-counting results in different locations, by calling or sending short text messages to each other. This meant they were able to pass on the same information to their respective media houses, which in turn would relay the information to the public.

Kenyan mainstream media now encourages opinion pieces written by outside commentators. The challenge here is to ensure that such contributions, which are often written by non-journalists, remain objective. Recent suspicions are that some regular commentators are on the payroll of politicians or political parties, and bend their opinions to suit certain interests. These writers veil their support for specific parties and individuals, providing politicians with another track to astutely penetrate the media and gain mileage. Fortunately, the mainstream media is now alert on such attempts, and has blacklisted some personalities in recent years.

In order to sustain good electoral coverage, the journalist-led Media Council of Kenya holds workshops aimed at equipping journalists with election-reporting skills. The ECK also conducts similar seminars for media players, telling them to exercise caution during electioneering periods. In time it is hoped more objectivity will be exercised and legal procedures observed, raising the standards of elections reportage in Kenya.

Election coverage requires that the journalist is knowledgeable about the area he or she 
has been assigned to cover. This means that the reporter must engage in research on the politics of the area, the voting patterns, the number of registered voters etc., in order to be able to provide the right information and analysis. Covering elections is as complex and adventurous as it is challenging. Below are some of the underlying hurdles faced by journalist when covering elections in Kenya:

- Denial by politicians of statements attributed to them, especially once they realise they have made a mistake. They tend to turn on the reporter and accuse him/her of having a hidden agenda, of 'misquoting' or quoting them 'out of context', regardless of whether they were caught on tape or not.

- Intimidation by politicians alone or by politicians and their supporters. This obstacle particularly affects regional (upcountry) correspondents, especially when they are filing stories by phone on location. There have been cases of supporters of particular candidates besieging reporters filing stories in this manner, to make sure they (the reporters) do not criticise their favourite candidate. For example, at a campaign rally just before the 2002 elections, a female parliamentary aspirant was seriously assaulted by alleged supporters of her competitor. The assailants then threatened the journalists covering the event (myself included), confiscated our cameras and recorders, and left us to run for our lives.

- Offers to be the 'media eye' of particular candidates, to ensure any negative stories about those candidates are quashed. Journalists have been offered large sums of monies to play such roles, and the pressure can be overbearing to the extent that some (usually reporters on low incomes) give in and start taking sides.

- Being caught up in the midst of election violence. Violent youth have in the past often vented their anger on journalists covering events. This happened on a number of occasions in the run up to the 2007 elections.

- The risk of being violently thrown out of a political rally for reporting on behalf of a particular media house, especially when the organisers are unhappy with that media organisation for 'not supporting' their cause. In other words, some politicians may expect a journalist to support their agenda (perhaps because they share the same neighbourhood or ethnicity) to the extent that the journalist is vilified (sometimes publicly) when he or she refuses and remains objective.

- Another challenge is the fatigue often associated with elections coverage. Vote counting takes place by hand and journalists must witness the process to completion.

- Accessing remote areas, where roads are terrible or even non-existent. How many media houses can hire helicopters to follow politicians flying in the same? Often, journalists are provided with transport by politicians, but how fair is their reporting going to be about the person who is responsible for their travel? ${ }^{35}$ 


\section{Commonwealth Observer Group report}

\section{Malawi Election, 2004}

Note: There are more than 30 registered political parties in Malawi, although only 15 of these took part in the elections, with two broad alliances. The ruling United Democratic Front (UDF) was in alliance with the Alliance for Democracy (AFORD) and the New Congress for Democracy (NCD). The opposition Mgwirizano Coalition comprised the Republican Party, the People's Progressive Movement (PPM), Malawi Forum for Unity and Development (Mafunde), Malawi Democratic Party (MDP), National Unity Party, Movement for Genuine Democratic Change (MGODE) and the People's Transformation Party. Other parties which participated in the election were the Malawi Congress Party (MCP), National Democratic Alliance (NDA), Congress for National Unity (CONU), National Solidarity Movement (NSM) and Pamodzi Freedom Party (PFP).

There were five Presidential candidates: Mr Gwanda Chakuamba Mgwirizano (Coalition), Mr Justin Malewezi (Independent), Mr Brown Mpinganjira (National Democratic Alliance), Dr Bingu wa Mutharika (UDF/AFORD/NCD) and Mr John Tembo (Malawi Congress Party). A total of 1,258 candidates contested the 193 parliamentary seats, including 373 independents.

\section{Media}

Ten years into multi-party democracy, the media in Malawi has diversified. The country now has a small but vigorous privately owned press and a handful of commercial radio stations. But the state-run Malawi Broadcasting Corporation (MBC) radio station, established in 1964, dominates the airwaves, as well as public broadcaster Television Malawi (TVM), which was set up in 1999; and the legacy of the country's first 30 years of one-party rule still shapes the information sector to an unhealthy degree.

None of the information outlets were without fault, but MBC radio deserves to be singled out for critical comment. It is the main, if not the sole, source of information for the majority of voters. This is why its responsibilities are set out in the Parliamentary and Presidential Elections Act (1993). Part V Section 63 (1) states that: 'Every political party shall have the right to have the substance of its campaign propaganda reported on radio news broadcasts of the Malawi Broadcasting Corporation and in any newspapers in circulation in Malawi.' Yet in the run-up to the 2004 election, MBC radio and TVM failed to meet the statutory terms and news output almost exclusively reflected the views of the ruling alliance.

Three decades of one-party rule under the first independent government of the Malawi Congress Party (MCP), which ruled from 1964 to 1994, have been instrumental in the conduct of the state-run media to date. Since 1994, with the transition of power from the 
MCP to the ruling UDF/AFORD alliance, the media monopoly has given way to allow the entry of private radio stations and newspapers. But the ruling coalition has continued to use the state media - MBC radio and TVM - for propaganda and political campaigns.

There have been many changes in all information sectors - newspapers, radio and television - since the first democratic elections in 1994 (when Commonwealth observers were last present) and the 1999 elections (which were assessed by a team from the Commonwealth Secretariat). The emergence of privately owned press and radio after decades of dominance by state-controlled media is undoubtedly a positive development, and one of the fruits of democracy.

\section{The emergence of privately owned press and radio after decades of dominance by state-controlled media is undoubtedly a positive development, and one of the fruits of democracy.}

\section{Radio}

$M B C$ radio remains the main source of news for the 70 to 80 per cent of Malawians who live in rural areas. Many cannot afford to buy a newspaper and, even if they could, newspapers are rarely available outside urban areas. Low literacy levels are a further barrier.

In terms of the level of coverage, $\mathrm{MBC}$ radio remains the most important medium of communication, followed by private radio stations (most of which are limited to the capital Lilongwe, Blantyre and Mzuzu), TVM and newspapers, in that order. MBC radio's transmitter footprint covers almost the entire country. Wireless ownership is fairly extensive, with almost every village thought to have at least one set for group listening. Private radio is extending steadily from the main urban centres, but its reach into the rural areas is dependent on the growth in advertising revenue, commercial sponsorship of programmes and the willingness of the government to grant transmitter licences.

The spillover of these new urban transmitters does allow for listening in rural areas within 30 kilometres or so radius. However, for a large majority of voters, MBC radio is the only source of information available to them. MBC radio has continued to give totally unlimited access to the incumbent party. This has produced a lack of balance in the amount of time given to news of the rallies, meetings, the manifestos, policies and personalities of the contesting parties and independent candidates.

On $\mathrm{MBC}$ radio, very little time was given in the main news bulletins to parties other than the 
ruling alliance of UDF/AFORD/NCD. Often during the campaign period, several days passed without any mention in the main news bulletins of the campaigns of opposition candidates or parties. Both MBC radio and TVM chose to restrict their extended coverage of election rallies to those of the ruling alliance's presidential candidate, Bingu wa Mutharika, almost all of which were dominated by the head of state, outgoing President Bakili Muluzi. The justification claimed for this monopoly of rally coverage is said to be the right of the head of state to have all his or her activities covered live by the media.

The degree of the imbalance was so large that the Commonwealth Media Adviser to the Malawi Electoral Commission (MEC) reported (from a detailed monitoring operation he had been supervising for the Commission since the beginning of the year) that over 90 per cent of all election coverage on $\mathrm{MBC}$ radio during the eight-week official campaign period had been about and of positive benefit to the ruling alliance (UDF/AFORD/NCD). The figure for TVM had been just over 80 per cent. In the final few days of campaigning, our observers saw a small measure of improvement in TVM's balance, but this was too late to be any remedy for the grossly undemocratic coverage throughout the official campaign period and before.

Of the private radio services, which are now having an impact and providing an alternative voice for the voters, Capital Radio (FM 102.5) - which broadcasts news bulletins every half hour - has provided the most balanced election coverage since the start of campaigning on 20 March.

The MEC Media Monitoring Unit noted that Capital Radio gave 24 per cent of its campaign coverage to the UDF/AFORD/NCD coalition; 24 per cent to the Mgwirizano Coalition; 20 per cent to the National Democratic Alliance (NDA); 15 per cent to independent candidate Justin Malewezi; 10 per cent to the Malawi Congress Party (MCP); and 7 per cent to others.

The Malawi Institute of Journalism (MIJ) radio (FM 90.3) and Power 101 FM, while giving substantial positive coverage to all the main parties, showed bias against the ruling UDF/AFORD/NCD alliance and its presidential candidate by the much larger amount of negative news broadcast about them compared with that given to opposition parties.

\section{Television}

TVM said it would work closely with the Electoral Commission and all the contesting political parties to provide coverage in the run-up to the Presidential and Parliamentary elections. However, 80 per cent of its election coverage was focused on the ruling alliance. TVM was one of the signatories to the Malawi National Peace Commitment, an initiative of the government-backed Forum for Dialogue and Peace that promoted dialogue, peace-building and non-violent conflict resolution within Malawian society. One of the principles of Chapter Six of the Commitment states that the media will commit itself: 'To provide all political parties equitable access to our media houses'. 
TVM said that there was a lack of equipment and resources to provide equitable coverage of all political parties during the campaign period. They argued that election coverage required additional resources such as transport, tapes, cameras and editing equipment, but that the station had not received any additional budget or equipment to support them. TVM was also unable to cover some political rallies as some parties had barred them from covering their events.

\section{Guidelines, monitoring and action}

Both $\mathrm{MBC}$ radio and TVM television have ignored key elements in the media guidelines and the requirements of the Parliamentary and Presidential Elections Act of 1993, the Local Government Elections Act of 1996, and the Communications Act of 1998, which all call for full, fair and balanced political coverage at all times in news and other broadcasts related to campaigns of all registered candidates and parties during the campaign period. These guidelines are intended to require that the media provide the public with civic education and information about the electoral process and the rights of each citizen to cast his/her ballot. Voter education is a crucial building block of democracy, and in this election, voter education and balanced information were inadequate.

At the request of the Electoral Commission, a media adviser was provided by the Commonwealth Secretariat for a series of visits from mid-2002 to May 2004. The adviser, Tim Neale, helped the Commission, the political parties and the news organisations to redraft the guidelines for media coverage of the elections. From January 2004 he was also tasked with establishing and supervising a media monitoring operation to allow the Commission to acquire detailed information about the relative balance being provided throughout the campaign by radio, television and the press. In the run-up to the elections, the Commonwealth Secretariat made clear that it was disturbed by the bias of the state media.

The Electoral Commission and the Malawi Communications Regulatory Authority (MACRA) failed to ensure that the media abided by the law by providing equal coverage to the political parties and their candidates during the campaign. The ruling UDF/AFORD/NCD coalition had a distinct advantage in the election campaign, with MBC radio and TVM at its disposal. Almost all of the ruling party's campaign rallies were covered in the news and in extended broadcasts often amounting to 20 hours per week. There was no distinction made between coverage of the head of state in the performance of his duties and his campaign advocacy for his UDF presidential candidate, Bingu wa Mutharika. There was a clear bias towards the ruling party led by President Muluzi and his chosen successor. Over 90 per cent of election coverage on MBC radio was given to the UDF/AFORD/NCD party.

The Electoral Commission acknowledged in a newspaper advertisement in the Weekend Nation (15-16 May 2004) that 'election coverage by MBC has been weighted in favour of 
the current government. This is unacceptable and poses a threat to democracy'. The Commission said it had 'requested the balance be redressed', but the pro-ruling party bias continued until the eve of polling day. MBC radio and TVM had agreed in writing to abide by the Electoral Commission's media guidelines on electoral coverage, but failed to do so.

\section{Party broadcasts}

Recordings of party manifestos that the Electoral Commission had sent to MBC radio on 3 May for broadcast were not aired. This contravenes Part V Section 63 (2) and Part V Section 63 (1) (b) of the Parliamentary and Presidential Elections Act (1993), which called for neutrality and balance. MBC radio said some political party broadcasts could not be aired due to the low quality of the programmes subcontracted to private production houses by the MEC, which was 'the substandard nature of some of the recordings'. MBC radio also cited 'the lack of commitment from some of the parties to record with $\mathrm{MBC}$ and the non-availability of opposition politicians for interviews'. Despite the setbacks faced by MBC radio, its spokesman said the station was determined to 'send out reporters to all the districts for unofficial results announcement'.

\section{The print media}

Several newspapers emerged during the pre-election period. While some ran strongly partisan stories and comment, most avoided the worst excesses of personal abuse directed at individual candidates.

The main permanent daily papers (The Nation and Daily Times) took, overall, a line against the ruling alliance (UDF/AFORD/NCD). Nevertheless, they still gave substantial coverage to the manifestos of all the main parties and coalitions. Readers of either paper would therefore, over the period of the campaign, have had the chance to absorb the main thrust of all the policies being proposed by all contenders.

So far as the weekly newspapers were concerned, The Chronicle, a weekly newspaper, was strongly against the ruling alliance and favoured the opposition. The Enquirer featured positive headlines and stories on the ruling UDF/AFORD/NCD coalition and negative stories on the opposition, portraying them as being in disarray, lacking co-operation and unity, with no manifestos and vision for the leadership of the country. The Saturday Post and Malawi Standard are pro-ruling alliance newspapers. The Exclusive, a pro-ruling coalition paper which emerged only early this year, was blatantly against the opposition, branding the candidates as liars and incompetent to govern the country.

\section{Voter education}

Both $\mathrm{MBC}$ radio and TVM performed poorly in providing voter education. $\mathrm{MBC}$ radio 
acknowledged that the station's role included civic education and information. Its representatives had met Electoral Commission officials in March 2003 to discuss voter education programmes and this led to the establishment of an $\mathrm{MBC}$ radio task force on elections. But MBC said it faced many constraints in producing programmes: it said that these included a lack of transport and allowances from the Electoral Commission for $\mathrm{MBC}$ radio reporters.

We [the observer group] noted that the NGO Gender Coordination Network co-operated with $\mathrm{MBC}$ radio to profile female parliamentary candidates in their campaign programmes.

TVM said it was not accredited as a civic education provider for the elections, but was open to co-operation with accredited NGOs responsible for civic education. It had worked with the National Democratic Institute and GTZ in running some political debates.

The print media did a better job in voter education compared to the electronic media. The Nation, Daily Times and The Chronicle featured articles on the candidates, with editorial comments and analysis of various political parties and the impact on the political landscape of the country if respective parties or candidates were voted into power.

The Nation ran a seven-page supplement on several occasions produced by the NGO Gender Coordination Network. This profiled female parliamentary candidates and highlighted the Southern Africa Development Community (SADC) objective that 30 per cent of parliamentarians in each member country should be female. 


\section{Commonwealth Observer Group report}

\section{Seychelles Election, 2006}

Note: The 2006 Presidential Election was contested by Mr James Michel (Seychelles People's Progressive Party [SPPF]); Mr Wavel Ramkalawan (SNP); and Mr Philippe Boullé (Independent).

\section{Media}

Seychelles does not have a large and diverse media industry; this is perpetuated by the prohibitive cost of establishing and operating a private television or radio station. The country is served mainly by the Seychelles Broadcasting Corporation (SBC), a state-owned public broadcaster that runs one television channel and one radio station. In addition to SBC, there is one daily newspaper, The Seychelles Nation, which is a government-owned newspaper whose mandate is to report government news and business.

Three weekly party newspapers exist: The People (SPPF), Regar (SNP) and Seychelles Weekly (DP). We heard that another newspaper, The Independent, resumed publication prior to the elections. The team did not, however, meet with the editor.

Given that there is no independent media in Seychelles, the role of SBC as the public broadcaster is of great importance. As a public broadcaster, the SBC should provide news and information in an impartial and balanced fashion.

The team commends SBC and the Electoral Commissioner for facilitating an agreement with the political parties which ensured all presidential candidates (and their parties) received equal opportunity to use SBC (television and radio) for party political broadcasts and spots (PPBs) to promote their agendas.

The team was able to see and hear some of the PPBs towards the end of the campaign, and see some of the news coverage relating to the campaign. There were allegations by political parties of unfair treatment in respect of coverage of their events and prejudicial portrayal of their views. 